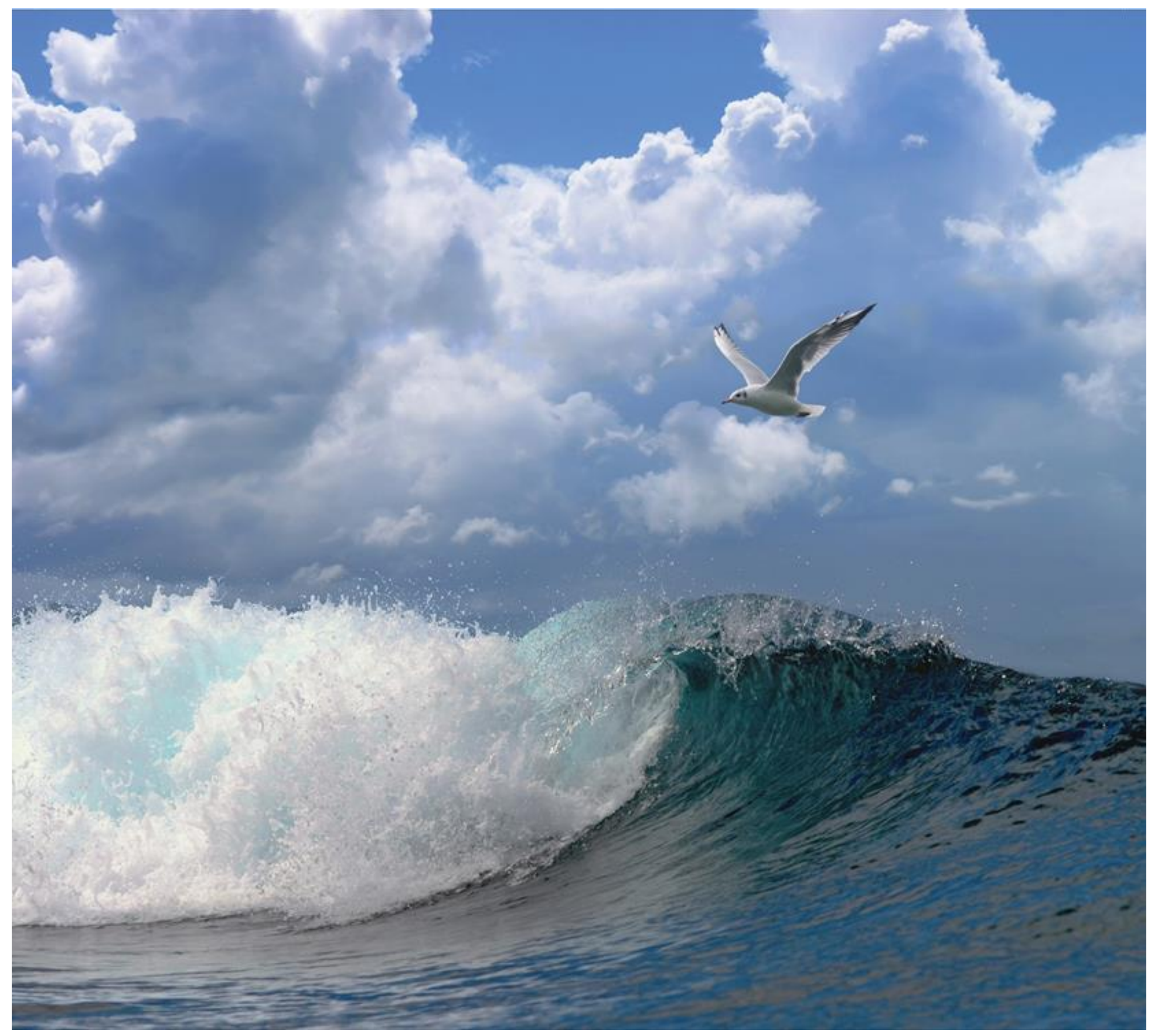

\title{
Development of the benthic macrofauna community after tidal restoration at Rammegors
}




\section{Development of the benthic macrofauna community after tidal restoration at Rammegors}

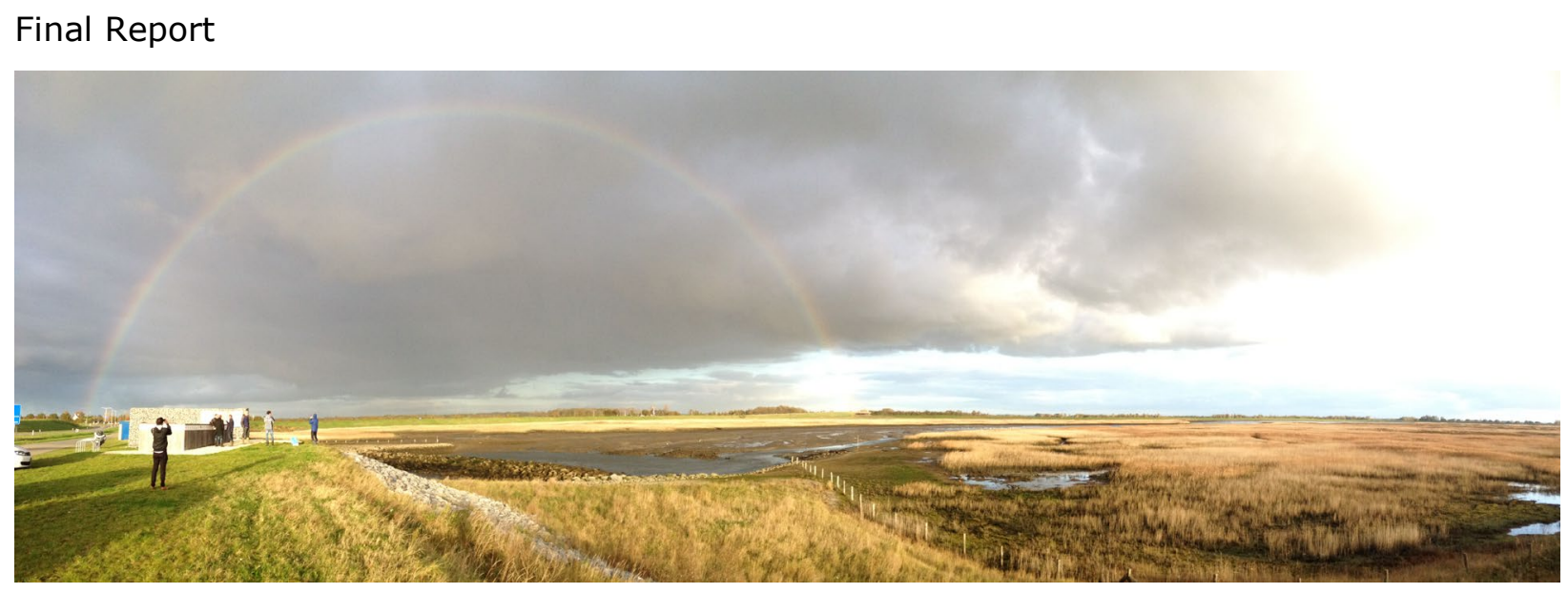

This report is part of the Rammegors monitoring project that was executed by the Centre of Expertise Delta Technology. This is a consortium formed by the University of Applied Sciences (Zeeland), Wageningen Marine Research, NIOZ and Deltares and financed by Rijkswaterstaat. This research was also partly financed by the Ministry of Public Affairs, within the framework of the Kennisbasis Programme System Earth Management (project KB-24-001-15). 
Keywords: macrofauna community, tidal recovery, Rammegors

Client: $\quad$ Rijkswaterstaat Zee en Delta

Poelendaelesingel 18

$4335 \mathrm{JA}$, Middelburg

BAS code KB-24-001-015

This report can be downloaded for free from https://doi.org/10.18174/475790

Wageningen Marine Research provides no printed copies of reports

Wageningen Marine Research is ISO 9001:2015 certified.

Photo cover: Brenda Walles

\section{(C) Wageningen Marine Research}

Wageningen Marine Research, an institute Wageningen Marine Research accepts no liability for consequential damage, nor within the legal entity Stichting Wageningenfor damage resulting from applications of the results of work or other data Research (a foundation under Dutch private obtained from Wageningen Marine Research. Client indemnifies Wageningen law) represented by Dr. M.C.Th. Scholten, Marine Research from claims of third parties in connection with this application. Managing Director All rights reserved. No part of this publication may be reproduced and / or published, photocopied or used in any other way without the written permission

KvK nr. 09098104, of the publisher or author.

WMR BTW nr. NL 8113.83.696.B16.

Code BIC/SWIFT address: RABONL2U

IBAN code: NL 73 RABO 0373599285 


\section{Contents}

$1 \quad$ Introduction $\quad 5$

1.1 Tidal recovery at Rammegors $\quad 5$

$\begin{array}{lll}1.2 & \text { Technical problems } & 6\end{array}$

$\begin{array}{ll}1.3 & \text { Monitoring }\end{array}$

$\begin{array}{llr}1.4 & \text { Research questions } & 7\end{array}$

$2 \quad$ Material and Methods $\quad 8$

$2.1 \quad$ Benthic sampling $r$

2.2 Statistical analysis $r$

$\begin{array}{llr}3 & \text { Results } & 11\end{array}$

$\begin{array}{lll}3.1 & \text { Environmental conditions } & 11\end{array}$

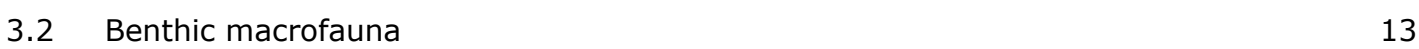

$\begin{array}{ll}3.3 \text { Community structure } & 16\end{array}$

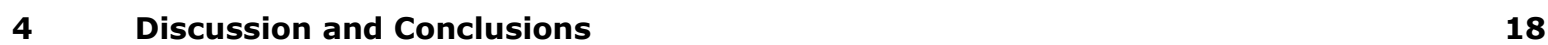

$\begin{array}{lr}\text { Acknowledgement } & 19\end{array}$

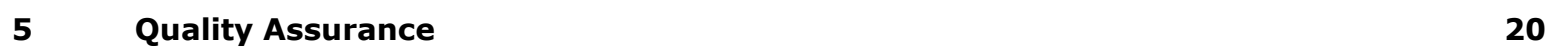

$\begin{array}{lr}\text { References } & \mathbf{2 1}\end{array}$

$\begin{array}{lr}\text { Justification } & \mathbf{2 2}\end{array}$ 


\section{Summary}

The managed realignment project Rammegors aims at re-establishing estuarine nature in a formerly freshwater wetland. For this purpose, a tidal inlet was constructed in the Krabbekreekdam to generate a reduced tidal influence that should allow the development of salt marsh area, tidal flat area and low energetic shallow sub-tidal area. A central question of the Rammegors tidal restoration project is how the flora and fauna will develop in the area.

To understand the biotic and abiotic processes related to the tidal restoration in Rammegors, a monitoring programme is being executed by the Centre of Expertise Delta Technology. The monitoring focuses on the main biotic and abiotic developments in the area. This report only focuses on the early colonization of macrobenthic invertebrates in Rammegors.

Benthic macrofauna and sediment sampling took place in spring and autumn 2017 and 2018 at twenty-four stations along 5 transects with varying distances from the inlet. A fast colonization of the benthic macrofauna was observed in Rammegors. Twenty-two taxa were observed in the area in spring 2017. The communities significantly differed between spring and autumn 2017. In spring densities reached high values, especially for the brackish mud shrimp Manocorophium insidiosum and mosquito larvae Chironomidae. In autumn these brackish species almost disappeared from the area. Their presence in autumn 2017 and spring 2018, even in low numbers, as well as the observation of the brackish cockle Cerastoderma glaucum indicate that a year after the tidal restoration, parts of Rammegors are still under influence of brackish water. In 2018 these species declined, indicating the transition to a marine environment.

A significant relation was found between elevation and the benthic macrofauna. Total density, biomass and species richness showed a significant relation along the elevation gradient with an optimum around $+0.4 \mathrm{~m}$ NAP and lower values at both lower and higher elevations. Total density significant increases with an increase in chlorophyll-a, silt content and organic matter. A significant decrease in total density and species richness was observed with increasing bulk density, indicating that more compact sediments contain less species in lower abundances. Total density, biomass and species richness increased with increasing distance from the inlet. After two years, it is unknown if the community within the Rammegors area reached stability or develops at a slow pace. Future monitoring and a comparison to a community found in a comparable natural habitat is needed to study this. 


\section{Introduction}

Intertidal areas, like mudflats, sand flats, seagrass beds and saltmarshes, are productive components of coastal ecosystems, characterized by a high primary production, sustaining benthic organisms that serve as food to many fish and waterbird species (Heip et al. 1995, Herman et al. 1999). Because of their value, these habitats are worldwide protected by international conventions and legislations, e.g. the Ramsar convention for the protection of migratory birds or the European Natura2000 legislation. It is also increasingly recognized that intertidal areas provide essential ecosystem services such as nutrient cycling, carbon storage, coastal protection and food production.

Despite these ecosystem services and protected status, intertidal areas are under pressure from human-induced changes that affect their quantity and quality (Lotze et al. 2006, Airoldi and Beck 2007). In the Oosterschelde estuary, intertidal areas are declining as a consequence of coastal defence infrastructures constructed in the 1980's. The construction of a storm surge barrier in the mouth of the Oosterschelde and two compartmentalization dams in the back of the system resulted in a decrease in tidal volume and tidal current velocities. Due to the decrease in tidal flow, the buildingup of intertidal flats has reduced. Consequently, the tidal flats in the Eastern Scheldt are eroding since the construction of the storm surge barrier. By 2100 less than half of the tidal flat area will remain in the Oosterschelde (de Ronde et al. 2013). The Dutch government (Rijkswaterstaat), responsible for the management of this Natura2000 area, implements projects to conserve or increase the intertidal area in the Oosterschelde.

\section{$1.1 \quad$ Tidal recovery at Rammegors}

In the 1970s, the Rammegors area was still part of the Oosterschelde, characterized by deep gullies, tidal flats and marshes (Figure 1). Construction of the Schelde-Rijndijk and Krabbenkreekdam in 1972 cut off the area from the Oosterschelde and changed Rammegors into a freshwater wetland. To increase intertidal areas and marshes in the Oosterschelde, Rammegors was reconnected to the Oosterschelde in December 2014, by constructing an inlet to reintroduce tidal influences into the Rammegors area after 40 years (Figure 2). Three culverts (width: $3.5 \mathrm{~m}$; length: 60m) generate a reduced tide that allow the development of typical salt marsh vegetation. The culverts will be closed when the water level at the Oosterschelde side is around $+1.65 \mathrm{~m} \mathrm{NAP}$. At the Rammegors side, a dam (Figure 3) was constructed near the inlet to limit the water outflow of the area, to ensure a shallow water area in the Rammegors (14 ha).
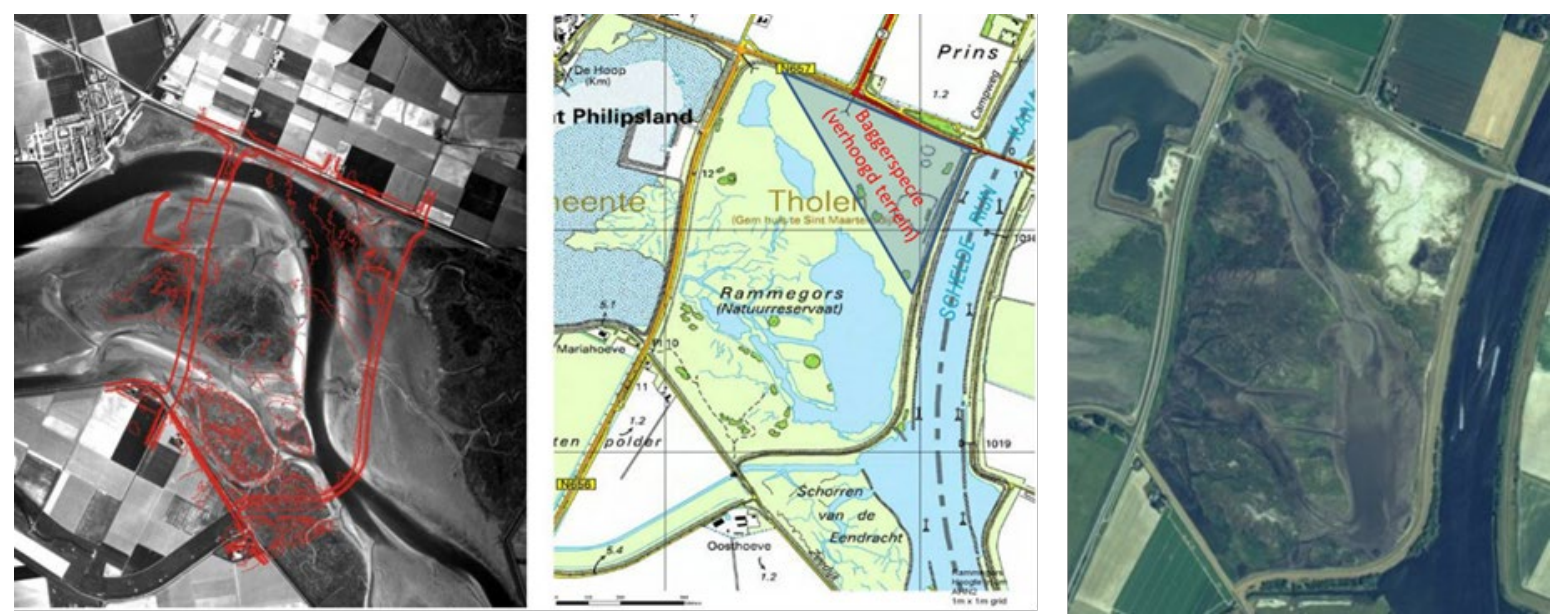

Figure 1 Aerial view of the Rammegors area from 1966 with overlay of the current situation in red (left) and the situation before constructing the inlet (middle), and the current situation during low tide (right). Source: Rijkswaterstaat and satellietdataportaal.nl. 


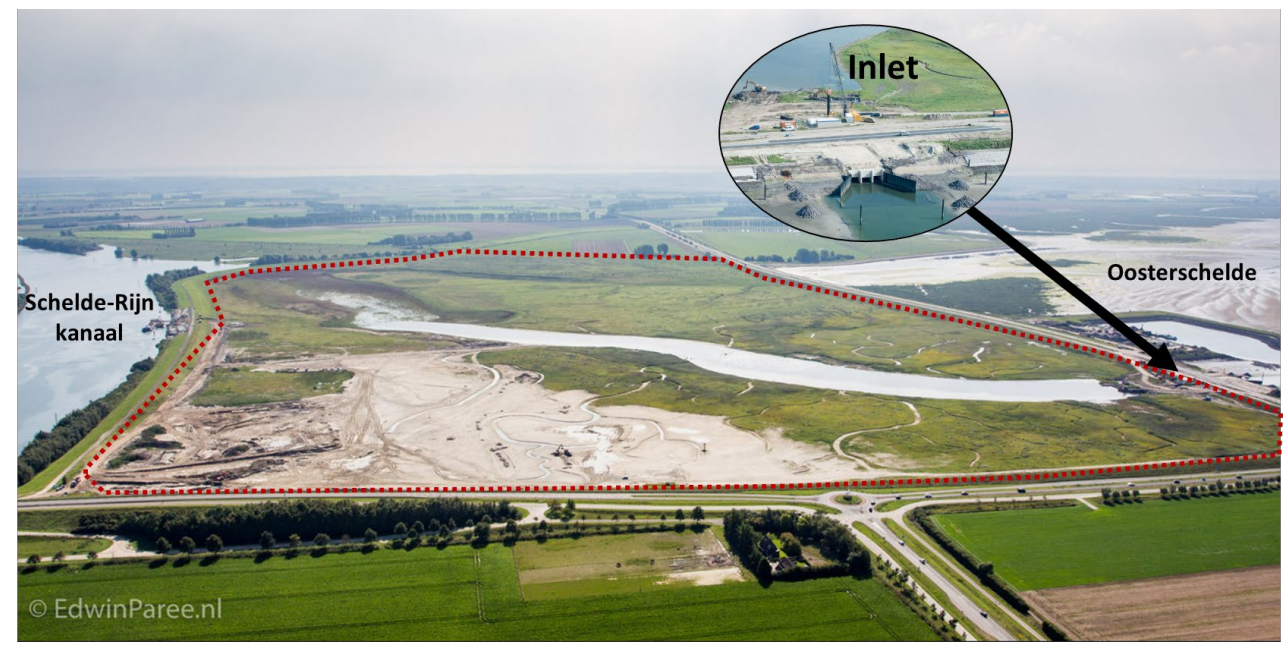

Figure 2 Aerial picture of the Rammegors area (red dotted line) during the construction of the inlet (September 2014). Photo: Edwin Paree
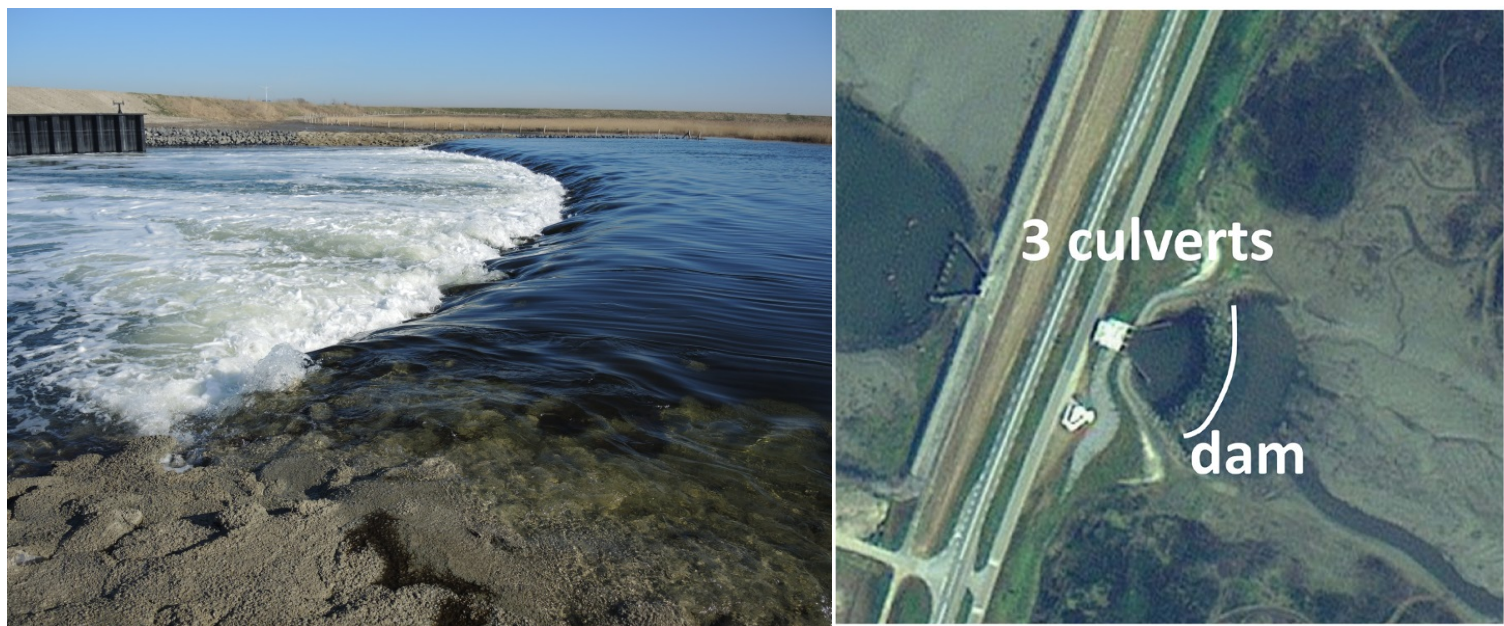

Figure 3 Left: Outflow of saltwater during ebb from the Rammegors (right side of photo) into the Oosterschelde through the three culverts in the Krabbenkreekdam (left side of photo). Photo: Tom Ysebaert. Right: Position of the dam in the Rammegors area and the three culverts in the inlet.

\subsection{Technical problems}

After the first opening on December $5^{\text {th }} 2014$, several unforeseen technical problems occurred:

- December $19^{\text {th }}$ 2014: culverts closed due to scour of the sandy channel bottom at the Eastern Scheldt side. A stagnant water body remained in the Rammegors area, covering $50 \%$ of the area.

- February $18^{\text {th }} 2015$ : culverts were opened after construction works ( ${ }^{\text {th }}$ opening).

- $\quad$ April 22 $2^{\text {th }}$ 2015: culverts actively closed due to a breach in the dam at the Rammegors side. Culverts remained closed during most part of the year for safety reasons. In this period both stagnant water covering $100 \%$ of the Rammegors area, as well as no water (0\%) was observed.

- $\quad$ December $5^{\text {th }} 2016$ : culverts opened after construction works ( $3^{\text {th }}$ opening).

- $\quad$ May $1^{\text {st }}$ 2017: culverts closed for one week to replace a cylinder. Stagnant water covering $75 \%$ of the Rammegors area.

- September $1^{\text {st }}$ 2017: culverts closed for one week to replace a sensor. Stagnant water covering $75 \%$ of the Rammegors area. 


\section{$1.3 \quad$ Monitoring}

The development of the Rammegors area from a stagnant freshwater area into a tidal system with intertidal mudflats and salt marshes depends on many factors related to the characteristics of the former freshwater area and the conditions of the adjacent estuarine environment.

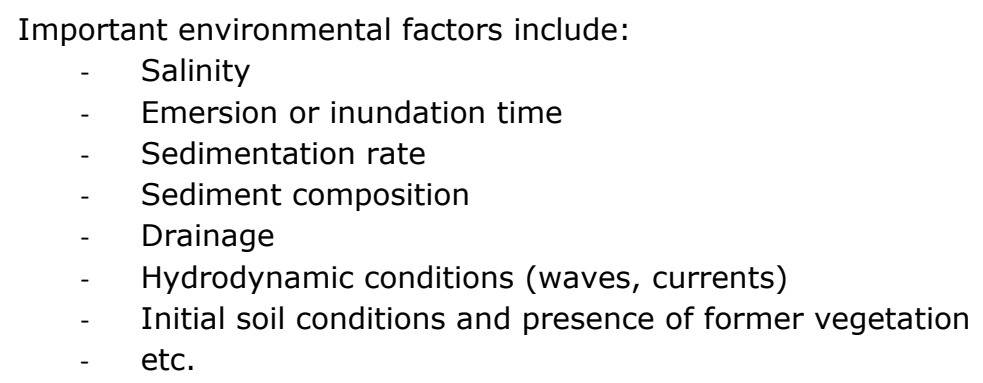

To understand the biotic and abiotic processes related to the tidal recovery in Rammegors, a monitoring programme was executed by the Centre of Expertise Delta Technology. This is a consortium formed by the University of Applied Sciences (Zeeland), Wageningen Marine Research, NIOZ and Deltares and financed by Rijkswaterstaat. The monitoring focuses on the most probable biotic and abiotic developments in the area; salinization through the groundwater of the surrounding polders, vegetation and soil development, and colonization by the benthic organisms.

This progress report only focuses on the early colonization of benthic macroinvertebrates in Rammegors. Due to the technical problems the first benthic sampling ( $T_{0}$ ) took place in spring 2017. This report presents data from the benthic sampling performed in spring and autumn 2017 and 2018 after the $3^{\text {th }}$ opening in December 2016, two years after the $1^{\text {st }}$ opening.

\subsection{Research questions}

A central question of the Rammegors tidal restoration project is how the habitat will develop in the area. Estuarine habitats will develop over time, but little is known about the spatial and temporal characteristics of this development. This report focus on the development of the benthic macrofauna. Intertidal and shallow subtidal habitats are important habitats for many species of macrobenthos, including polychaetes, molluscs and crustaceans. These organisms are central elements of the estuarine foodweb, as they are important consumers of phytoplankton and microphytobenthos, and on the other hand are a crucial food source for higher trophic levels such as birds and fish.

The intertidal benthic biota have to survive in a harsh and variable environment. Temperature, light, emersion time and water saturation vary not only according to tidal and diurnal rhythms, but also with seasonal and short-term weather variations. Physical stress is exerted by tidal currents and waves, the impact of which varies in space and time.

The main questions related to the Rammegors project are:

1. How do benthic macrofauna communities develop in relation to:

- the elevation gradient;

- the presence of the existing (remaining) freshwater vegetation;

- the presence of the developing salt marsh vegetation;

- the sedimentation rate in the area?

2. Are benthic communities in Rammegors similar to benthic communities in similar ecotopes in the Oosterschelde?

3. How do the developments of Rammegors compare to the developments of Perkpolder in the Westerschelde? What can be learned about the design of de-polder areas? 


\section{$2 \quad$ Material and Methods}

\subsection{Benthic sampling}

To quantify the colonisation of macrobenthic infauna and their community structure twenty stations, along four transects with varying distances from the inlet, were sampled within Rammegors in 2017 (Figure 4, A, B, C, D). In 2018 an additional transect (E, Figure 4) was added at the end of the creek. The transects cross the main tidal creek and include the creek and creek banks without vegetation. Large parts of Rammegors were still covered with reed (Elschot et al. 2016) or remnant plant parts. Sampling stations were located between remnant plant parts (station 7 and 10), areas with newly established plants (Salicornia europaea) (station 3 and 11), permanently submerged areas (station 5 , 9,13 and 23) or on the unvegetated tidal flat (stations $1,2,4,6,8,12,14,15,16,17,18,19,20$, 21,22 and 24). None of the sampling stations were located in areas covered in reed due to sampling difficulties. These twenty-four stations were sampled on May $17^{\text {th }}$ (spring) 2017, September $5^{\text {th }}$ (autumn) 2017, June 14 $4^{\text {th }}$ (spring) 2018 and September $3^{\text {th }}$ (autumn) 2018 (Figure 5).

Macrobenthic infauna was sampled using a cylindrical $10 \mathrm{~cm}$ in diameter corer, i.e. $78 \mathrm{~cm}^{2}$ surface area to a maximum depth of $35 \mathrm{~cm}$. Due to plant remains and roots we could not sample up to $35 \mathrm{~cm}$ in depth at most locations. Three replicates were taken randomly at each station, pooled and sieved in the field through a $1 \mathrm{~mm}$ mesh sieve. The residue was preserved in $4 \%$ buffered formaldehyde solution and stained with Rose Bengal. In the lab specimens were sorted and identified to the lowest possible level, counted, wet weighted and preserved (in $4 \%$ buffered formaldehyde solution). The amount of individuals per species found at each station was converted to density (number of species $\mathrm{m}^{-2}$ ). Worm counts were bases on the number of heads found in a sample. When only tails were found they were recorded as one individual of this species. Biomass was calculated by converting total wet weight per station per species to total ash free dry weight (AFDW) in $\mathrm{g} \mathrm{m}^{-2}$ using species specific conversion factors as described in Craeymeersch and Escaravage (2014). In addition, Arenicola marina densities were counted by counting heaps in the field within $0.25 \mathrm{~m}^{2}(\mathrm{n}=10)$ at each sampling station. At each station a single sediment sample $\left(18.5 \mathrm{~cm}^{3}\right.$ ) was collected from the upper $3 \mathrm{~cm}$ (using a 1.4 in diameter syringe from which the tip was cut off) and stored in a preweighed sample bottle. In addition salinity of the surface water was measured at each transect in the main gully in spring 2017.

Samples were wet weighted and placed in a freezer for a minimum of 3 days before opening the bottles and freeze dry (Christ ${ }^{\circ}$ Alpha $\left.1-4\right)$ the sediment samples for 4 days $\left(-50^{\circ} \mathrm{C}\right)$. Samples were reweighed after freeze drying. Bulk density of the sediment $\left(\mathrm{g} \mathrm{cm}^{-3}\right)$ was calculated as ratio dry weight to the sampled volume. Sediment particle size distribution was determined by laser diffraction (Malvern Mastersizer 2000), from which the median grain size of the sediment $D_{50}(\mu \mathrm{m})$ as well as the size distribution (percentage coarse, medium, fine and very fine sand, and silt) was derived. Elevations (m NAP) were measured using a differential GPS device with a horizontal and vertical measure accuracy of 8 and $13 \mathrm{~mm}$, respectively (Leica GS12, Leica Geosystems AG, Switzerland, correction signal: SmartNet, Leica Geosystems, the Netherlands). Additional, Chlorophyll a $\left(\mu \mathrm{g} \mathrm{cm}{ }^{3}\right)$, as a measure for food availability for benthic animals, was measured by three pooled sediment samples collected from the upper $1 \mathrm{~cm}$ of the sediment, using a $1 \mathrm{~cm}$ in diameter syringe from which the tip was cut off. The samples were stored in the dark at $-80^{\circ} \mathrm{C}$ after which they were freeze dried and analysed spectrophotometrically according to Aminot and Rey (2002). 


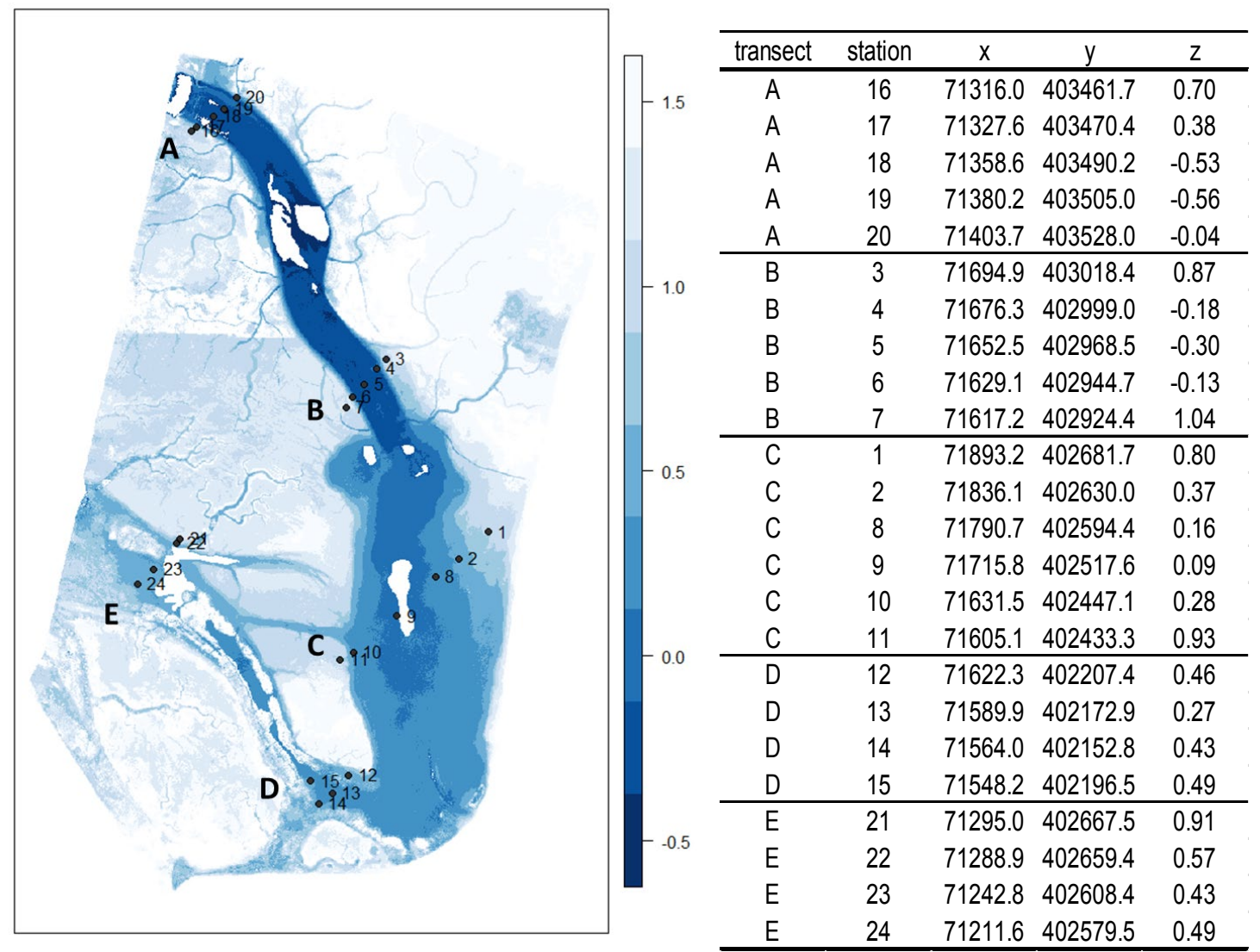

Figure 4 The twenty four benthic sampling points, along 5 transects ( $A$ till $E$ ), in Rammegors (2 by $1 \mathrm{~km}$ ) (left). $X, Y, Z$ coordinates of the benthic sampling stations ( $Z$ in $m N A P$, situation September 2018) are presented in the right table. Stations 21 to 24 were only sampled in 2018.

Based on the benthic macroinfauna samples several biological indicators were defined and linked to abiotic parameters. We defined:

(1) Species richness, which is a measure of the diversity (number of different taxa) of the macrofauna community at each sampling station. Species richness is the number of taxa found in the sample. As this is dependent on the sampled surface it is not expressed per $\mathrm{m}^{2}$ but per station.

(2) Density, which is the amount of individuals per species found in the cores, converted to number of individual species $\mathrm{m}^{-2}$.

(3) Biomass, which is the total wet weight per station per species converted to the total ash free dry weight in $\mathrm{g} \mathrm{m}^{-2}$ using species specific conversion factors as described in Craeymeersch and Escaravage (2014).
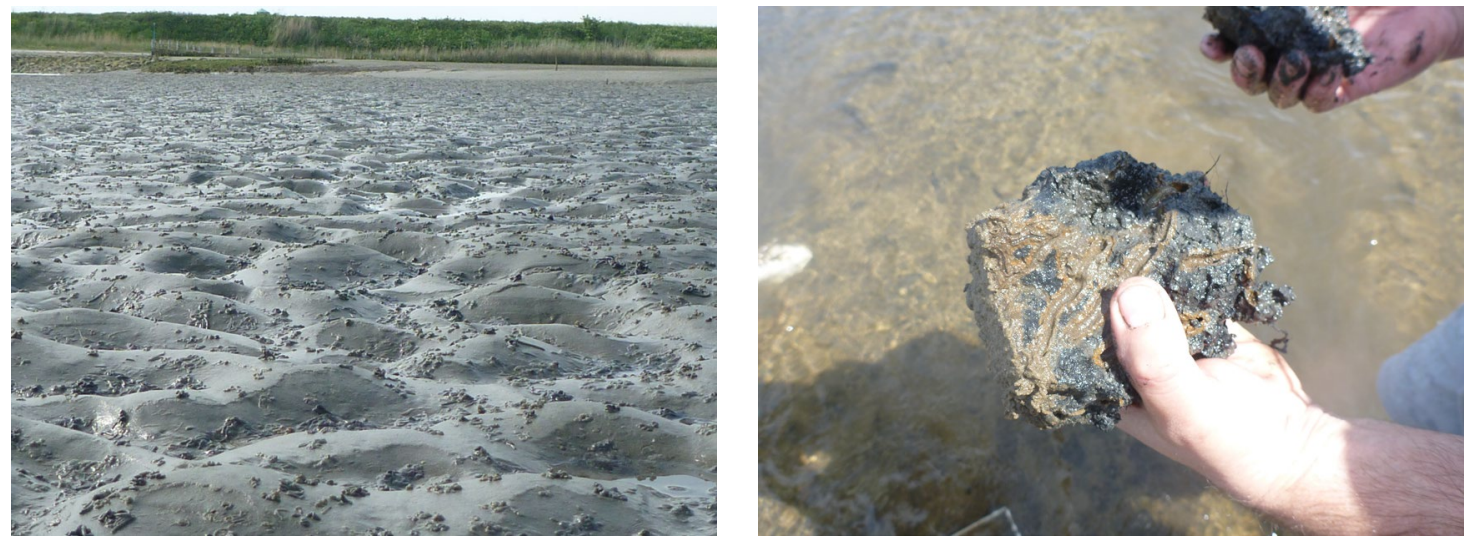

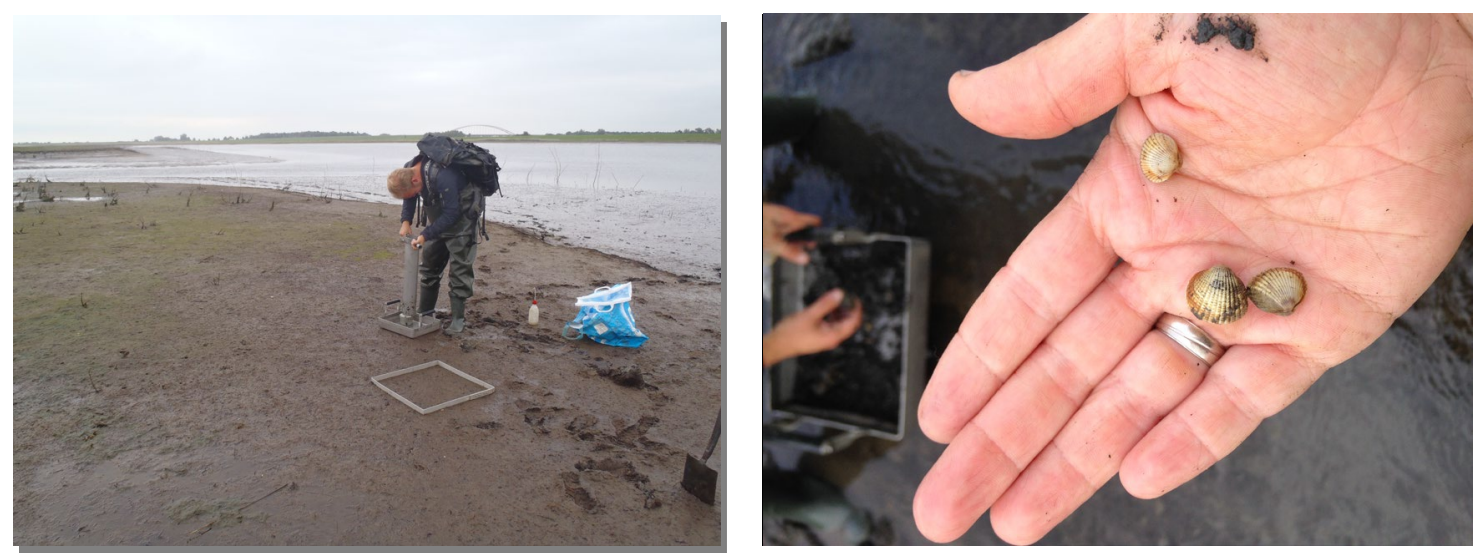

Figure 5 Benthic macrofauna sampling in the Rammegors area, May 2017 (top photos) and September (bottom photos) 2017. Notice the thick peat layer (top right photo). First cockels (C. edule and C. glaucum) observed in autumn 2017 (bottom right photo). Photos: Tom Ysebaert \& Brenda Walles

\subsection{Statistical analysis}

\section{Multivariate}

Changes in macroinvertebrate community composition was analysed with NMDS ordination (with the package "vegan" in R) which was run for 20 iterations at $k=2$ (decreased number of dimensions) before obtaining a solution. Abundance was square root transformed, and then submitted to Wisconsin double standardization to down-weight the importance of the highly abundant species allowing for the mid-range and rare species to exert influence on the calculation of similarity. Rare species, of which only one individual was found, were removed. Twenty-one taxa were included in the multivariate analysis.

Regression analyses were performed for species richness, density and biomass in relation to the abiotic data (elevation, $d_{50}$, \% silt, chlorophyll a, bulk density and organic matter). 


\section{Results}

\subsection{Environmental conditions}

Throughout the sampling period elevations did not change when considering all sampling stations in the Rammegors area (Figure 6, Table 1). However, when zooming in on the separate transects (Figure 7 ), lowering in elevation was observed near the inlet (transect $A$ to $C$ ), whereas an increase was observed at a greater distance from the inlet (transect D, E). Figure 7 also shows that sampling stations near the inlet are lower positioned than those at the end or the creek. Overall median grain size decreased over time (Figure 6). Median grain size decreased with distance from the inlet (Figure 7). Near the inlet a decrease in grain size was observed in spring 2018 (Transect A and B) followed by an increase in autumn 2018 (Figure 7). At a greater distance from the inlet the opposite was observed. Changes in median grain size coincide with changes in silt content (Figure 6 and 7). Percentage silt increased with distance from the inlet (Figure 7) and overall increased in time (Figure 6). Bulk density shows a decrease with distance from the inlet. After the first sampling in spring 2017 bulk density increases throughout the whole area which might indicate compaction of the sediment. It is however unknown why bulk density decreases again after this increase. Overall organic matter did not show changes over time. Chlorophyll a decreases over time. However, looking at the separate transects a small increase in both organic matter and chlorophyll a can be observed near the inlet (Transect $A$ and $B$ ) whereas a decrease occurred at some distance from the inlet (Transects C, D and E). Both parameters show an increases form the inlet to the end of the creak. Salinity of the surface water was high being 31 at each transect.

Table 1. Summary of mean values and their standard errors between brackets for abiotic characteristics and biological indicators of the Rammegors area in 2017 and 2018

\begin{tabular}{|c|c|c|c|c|}
\hline \multirow{3}{*}{ Parameter } & \multicolumn{4}{|c|}{ Rammegors area } \\
\hline & \multicolumn{2}{|c|}{$2017(n=20)$} & \multicolumn{2}{|c|}{$2018(n=24)$} \\
\hline & spring & autumn & spring & autumn \\
\hline \multicolumn{5}{|l|}{$\begin{array}{l}\text { Abiotic } \\
\text { characteristics }\end{array}$} \\
\hline$d_{50}(\mathrm{~mm})$ & $101.6(11.2)$ & 102.4 & $91.4(9.3)$ & $93.1(9.1)$ \\
\hline Coarse sand $(\%)$ & $0.3(0.2)$ & $0.1(0.1)$ & $0.4(0.1)$ & $0.4(0.1)$ \\
\hline Medium sand (\%) & $6.8(1.4)$ & $5.6(0.8)$ & $5.9(0.9)$ & $5.6(0.1)$ \\
\hline Fine sand $(\%)$ & $34.1(4.5)$ & $35.8(4.9)$ & $29.7(3.7)$ & $29.6(3.8)$ \\
\hline Very fine sand $(\%)$ & $27.7(1.5)$ & $27.6(1.5)$ & $27.0(1.9)$ & $28.5(1.4)$ \\
\hline Clay/silt (\%) & $31.3(5.5)$ & $31.0(6.0)$ & $37.2(4.6)$ & $36.1(4.5)$ \\
\hline elevation (m NAP) & $0.37(0.09)$ & $0.37(0.09)$ & $0.38(0.08)$ & $0.33(0.09)$ \\
\hline Chlorophyll-a $\left(\mu g^{-1}\right)$ & $36.4(8.3)$ & $30.2(7.6)$ & $25.2(4.0)$ & $24.4(3.4)$ \\
\hline Organic matter (\%) & $9.0(2.0)$ & $7.2(1.7)$ & $5.8(1.3)$ & $8.7(1.6)$ \\
\hline Bulk density () & $1.08(0.10)$ & $1.93(0.11)$ & $1.54(0.07)$ & $1.66(0.08)$ \\
\hline \multicolumn{5}{|l|}{ Macrofauna } \\
\hline No. of taxa & $10.0(0.9)$ & $5.9(0.7)$ & $7.8(0.7)$ & $7.4(0.7)$ \\
\hline No. of ind. $\left(\mathrm{m}^{-2}\right)$ & 8049 (1779) & 3028 & $3149(819)$ & $4122(735)$ \\
\hline Biomass $\left(\mathrm{g} \mathrm{m}^{-2}\right)$ & $6.14(1.21)$ & $5.66(1.01)$ & $5.61(0.94)$ & $11.23(1.46)$ \\
\hline
\end{tabular}



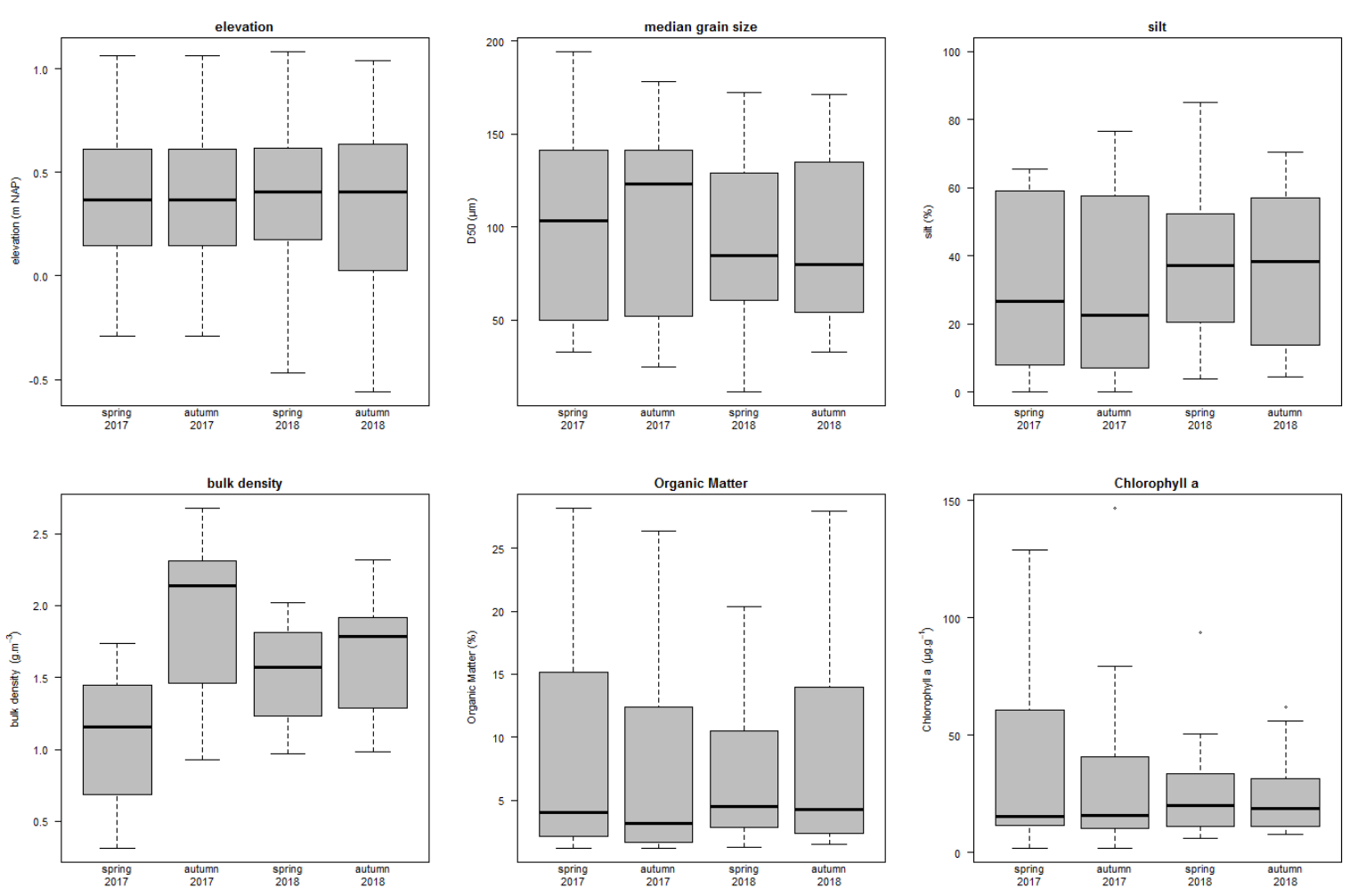

Figure 6 Changes in elevation (m NAP), median grain size (\%), silt (\%), bulk density $\left(g \mathrm{~cm}^{-3}\right)$, organic matter $(\%)$ and chlorophyll-a $\left(\mu \mathrm{g} \mathrm{cm}^{3}\right)$ in time in the whole Rammegors area.
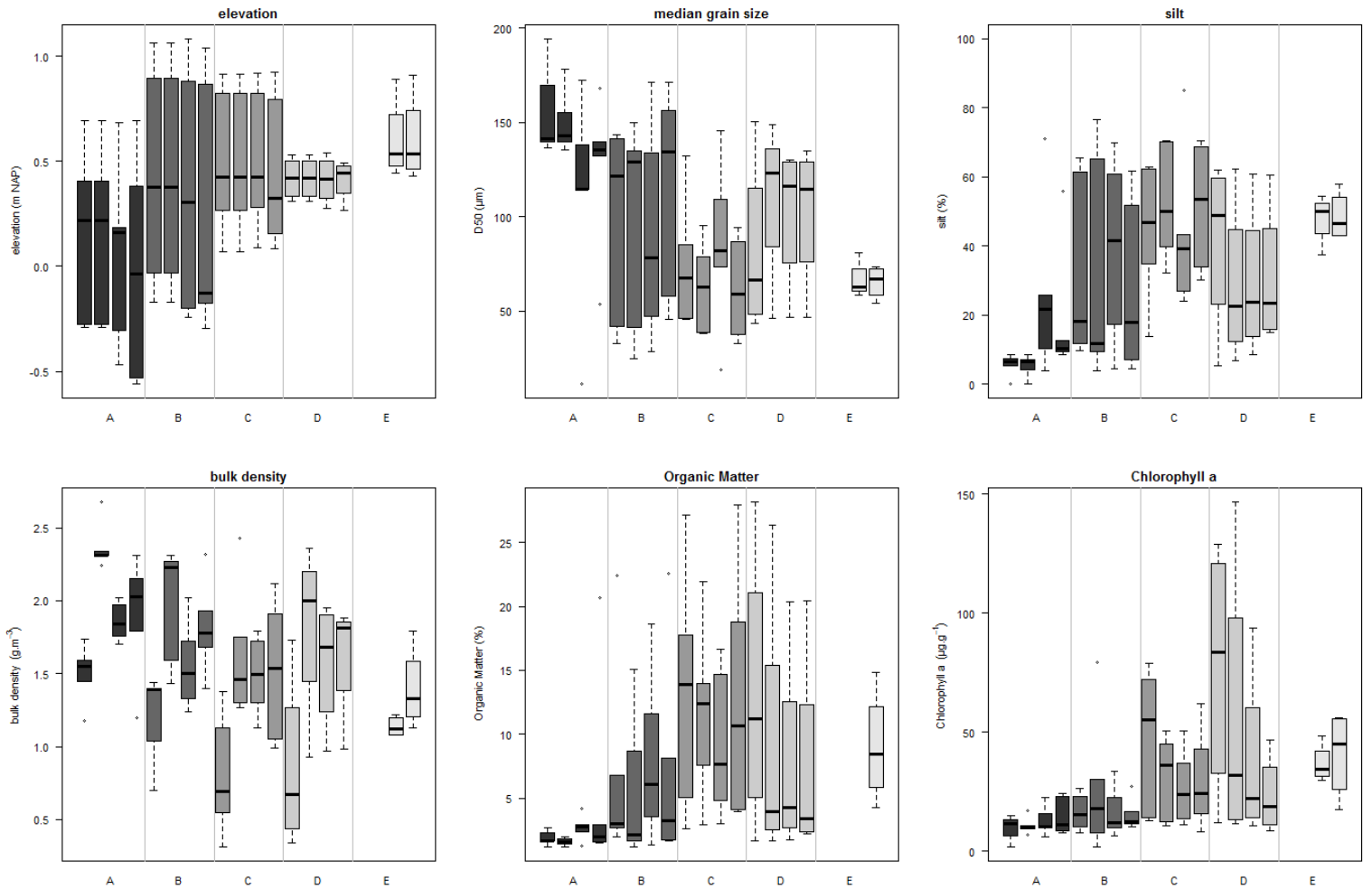

Figure 7 Changes in elevation (m NAP), median grain size (\%), silt (\%), bulk density $\left(\mathrm{g} \mathrm{cm}^{-3}\right)$, organic matter (\%) and chlorophyll-a $\left(\mu \mathrm{g} \mathrm{cm}^{3}\right)$ with increasing distance to the inlet (panels) over time (spring 2017, autumn 2017, spring 2018, autumn 2018). A, B, C, D and $E$ refer to the different transects indicated in Figure 4. 


\subsection{Benthic macrofauna}

A rapid colonization was observed as 22 species colonized the Rammegors area within five months after the third opening. During each subsequent sampling campaign new species colonize the area (Table 2). In spring 2017, the brackish mud shrimp Monocorophium insidiosum (Crawford 1937) occurred in $80 \%$ of the sampling stations and was by far the most dominant species in abundance (Table 2). M. insidiosum declined in autumn 2017 to only $1.5 \%$ of the density found in spring and disappeared completely from the area in autumn 2018. From autumn 2017 onwards the marine Corophium volutator increased in abundance. The observed decrease of $M$. insidiosum combined with an increase of $C$. volutator indicate that the Rammegors area was still brackish five months after the third opening but transferred to a marine system. Also the occurrence of the brackish cockle Cerastoderma glaucum, as well as high occurrence of Chironomidae in 2017 followed by a decline in 2018 indicates this transition. In autumn 2018 the Rammegors area was dominated by gastropoda and polychaeta of which Peringia ulvae and Corophium volutator, respectively contributed most to the total abundance (Figure 8B). Biomass (Figure 8C) increased over time, with polychaetes contributing most to the total biomass.

All biological indicators show a significant relation along the elevation gradient with an optimum around +0.4m NAP and lower values at both lower and higher elevations (Species richness: polynomial regression: $\mathrm{R}^{2}=0.11, p=0.006$; total density: polynomial regression: $\mathrm{R}^{2}=0.18, p=0.000$; total biomass: polynomial regression: $\mathrm{R}^{2}=0.30, p=0.000$ ) (Figure 9 ). Total density significantly increases with an increase in chlorophyll a (linear regression: $\mathrm{R}^{2}=0.23, p=0.000$ ), silt content (linear regression: $\mathrm{R}^{2}=0.10, p=0.003$ ) and organic matter (linear regression: $\mathrm{R}^{2}=0.08, p=0.009$ ). $\mathrm{A}$ significant decrease in total density (linear regression: $\mathrm{R}^{2}=0.29 p=0.000$ ) and species richness (linear regression: $\mathrm{R}^{2}=0.05, p=0.030$ ) was observed with increasing bulk density (Figure 10). All biological indicators show a significant linear increase with distance from the inlet (species richness: $R^{2}$ $=0.08, p=0.007$; total density: $\mathrm{R}^{2}=0.16, p=0.000$; total biomass: $\mathrm{R}^{2}=0.12, p=0.001$ ) (Figure 11 ). No relation between sediment composition and benthic macrofauna was found. 
Table 2. Occurrence (\% of the total sampled stations) and density (ind. $\mathrm{m}^{-2}$, mean \pm se) of the observed species/taxon in the Rammegors area. $N=20$ in 2017, and $n=24$ in 2018.

\begin{tabular}{|c|c|c|c|c|}
\hline \multirow[b]{2}{*}{ species/Taxon } & \multicolumn{4}{|c|}{ Occurrence \% } \\
\hline & $\begin{array}{c}\text { Spring } \\
2017 \\
\end{array}$ & $\begin{array}{c}\text { Autumn } \\
2017\end{array}$ & $\begin{array}{c}\text { Spring } \\
2018 \\
\end{array}$ & $\begin{array}{l}\text { Autum } \\
\text { n } 2018 \\
\end{array}$ \\
\hline Monocorophium insidiosum & 80 & 10 & 20 & \\
\hline Chironomidae & 75 & 10 & 10 & 10 \\
\hline Hypereteone foliosa & 75 & 50 & 50 & 25 \\
\hline Arenicola marina & 70 & 25 & 30 & 5 \\
\hline Capitella capitata & 70 & 30 & 15 & 50 \\
\hline Hediste diversicolor & 65 & 80 & 105 & 115 \\
\hline Nereis & 65 & 60 & 80 & 60 \\
\hline Polydora cornuta & 65 & 10 & 70 & 35 \\
\hline Oligochaeta & 60 & 5 & 30 & 15 \\
\hline Pygospio elegans & 55 & 20 & 45 & 20 \\
\hline Peringia ulvae & 45 & 45 & 75 & 80 \\
\hline Gammarus & 35 & & & \\
\hline Microdeutopus gryllotalpa & 35 & 5 & 10 & 5 \\
\hline Streblospio benedicti & 35 & 30 & 45 & 50 \\
\hline Eteone & 30 & 5 & 5 & 15 \\
\hline Gammarus locusta & 30 & & 5 & \\
\hline Arenicola & 20 & 15 & 10 & 5 \\
\hline Heteromastus filiformis & 20 & 60 & 50 & 85 \\
\hline Idotea & 15 & & & \\
\hline Insecta & 5 & 10 & 10 & 5 \\
\hline Phyllodoce mucosa & 5 & 5 & & \\
\hline Praunus & 5 & & & \\
\hline Alitta virens & & 40 & 30 & 65 \\
\hline Limecola balthica & & 20 & 30 & 40 \\
\hline Aphelochaeta & & 10 & 40 & 55 \\
\hline Carcinus maenas & & 10 & 5 & 10 \\
\hline Cerastoderma edule & & 10 & 10 & 5 \\
\hline Actiniaria & & 5 & & \\
\hline Alitta succinea & & 5 & & 15 \\
\hline Cerastoderma glaucum & & 5 & & \\
\hline Corophium volutator & & 5 & 75 & 35 \\
\hline Crangon crangon & & 5 & 15 & 10 \\
\hline Bivalvia & & & 10 & 15 \\
\hline Nemertea & & & 10 & 15 \\
\hline Tapes & & & 10 & 5 \\
\hline Cerastoderma & & & 5 & \\
\hline Gastropoda & & & 5 & \\
\hline Melita palmata & & & 5 & \\
\hline Scrobicularia plana & & & 5 & 5 \\
\hline Spio martinensis & & & 5 & \\
\hline Mya arenaria & & & & 10 \\
\hline Glycera tridactyla & & & & 5 \\
\hline Magelona & & & & 5 \\
\hline Nephtys hombergii & & & & 5 \\
\hline Ruditapes philippinarum & & & & 5 \\
\hline Spionidae & & & & 5 \\
\hline
\end{tabular}

\begin{tabular}{|c|c|c|c|c|}
\hline \multirow[b]{2}{*}{ species/Taxon } & \multicolumn{4}{|c|}{ Density (ind. $\mathrm{m}^{-2}$ ) } \\
\hline & Spring 2017 & Autumn 2017 & Spring 2018 & Autumn 2018 \\
\hline Monocorophium insidiosum & $3735 \pm 1066$ & $446 \pm 74$ & $2143 \pm 716$ & \\
\hline Chironomidae & $1949 \pm 531$ & $106 \pm 20$ & $191 \pm 34$ & $64 \pm 7$ \\
\hline Hypereteone foliosa & $195 \pm 43$ & $115 \pm 26$ & $59 \pm 7$ & $93 \pm 16$ \\
\hline Arenicola marina & $340 \pm 80$ & $119 \pm 21$ & $50 \pm 4$ & $42 \pm 0$ \\
\hline Capitella capitata & $243 \pm 42$ & $156 \pm 30$ & $71 \pm 11$ & $110 \pm 27$ \\
\hline Hediste diversicolor & $405 \pm 123$ & $899 \pm 194$ & $594 \pm 89$ & $961 \pm 205$ \\
\hline Nereis & $552 \pm 216$ & $509 \pm 134$ & $180 \pm 38$ & $453 \pm 138$ \\
\hline Polydora cornuta & $274 \pm 63$ & $127 \pm 27$ & $224 \pm 44$ & $218 \pm 44$ \\
\hline Oligochaeta & $2278 \pm 762$ & $4923 \pm 0$ & $85 \pm 8$ & $42 \pm 0$ \\
\hline Pygospio elegans & $293 \pm 56$ & $64 \pm 12$ & $292 \pm 57$ & $212 \pm 40$ \\
\hline Peringia ulvae & $292 \pm 57$ & $2735 \pm 669$ & $993 \pm 332$ & $2546 \pm 736$ \\
\hline Gammarus & $194 \pm 61$ & & & \\
\hline Microdeutopus gryllotalpa & $770 \pm 263$ & $212 \pm 0$ & $1528 \pm 416$ & $42 \pm 0$ \\
\hline Streblospio benedicti & $449 \pm 99$ & $212 \pm 55$ & $141 \pm 33$ & $127 \pm 21$ \\
\hline Eteone & $71 \pm 10$ & $0 \pm 0$ & $42 \pm 0$ & $28 \pm 5$ \\
\hline Gammarus locusta & $78 \pm 7$ & & $42 \pm 0$ & \\
\hline Arenicola & $64 \pm 5$ & $42 \pm 16$ & $21 \pm 7$ & $42 \pm 0$ \\
\hline Heteromastus filiformis & $74 \pm 21$ & $258 \pm 114$ & $68 \pm 12$ & $135 \pm 39$ \\
\hline Idotea & $71 \pm 11$ & & & \\
\hline Insecta & $42 \pm 0$ & $42 \pm 0$ & $64 \pm 7$ & $127 \pm 0$ \\
\hline Phyllodoce mucosa & $85 \pm 0$ & $85 \pm 0$ & & \\
\hline Praunus & $42 \pm 0$ & & & \\
\hline Alitta virens & & $80 \pm 15$ & $71 \pm 10$ & $98 \pm 16$ \\
\hline Limecola balthica & & $53 \pm 5$ & $42 \pm 0$ & $58 \pm 7$ \\
\hline Aphelochaeta & & $64 \pm 7$ & $101 \pm 13$ & $278 \pm 68$ \\
\hline Carcinus maenas & & $42 \pm 0$ & $42 \pm 0$ & $42 \pm 0$ \\
\hline Cerastoderma edule & & $42 \pm 0$ & $42 \pm 0$ & $85 \pm 0$ \\
\hline Actiniaria & & $42 \pm 0$ & & \\
\hline Alitta succinea & & $42 \pm 0$ & & $14 \pm 5$ \\
\hline Cerastoderma glaucum & & $42 \pm 0$ & & \\
\hline Corophium volutator & & $42 \pm 0$ & $1092 \pm 478$ & $2213 \pm 718$ \\
\hline Crangon crangon & & $42 \pm 0$ & $57 \pm 5$ & $64 \pm 7$ \\
\hline Bivalvia & & & $21 \pm 7$ & $424 \pm 75$ \\
\hline Nemertea & & & $42 \pm 0$ & $99 \pm 22$ \\
\hline Tapes & & & $42 \pm 0$ & $85 \pm 0$ \\
\hline Cerastoderma & & & $42 \pm 0$ & \\
\hline Gastropoda & & & $42 \pm 0$ & \\
\hline Melita palmata & & & $42 \pm 0$ & \\
\hline Scrobicularia plana & & & $42 \pm 0$ & $42 \pm 0$ \\
\hline Spio martinensis & & & $85 \pm 0$ & \\
\hline Mya arenaria & & & & $64 \pm 7$ \\
\hline Glycera tridactyla & & & & $42 \pm 0$ \\
\hline Magelona & & & & $0 \pm 0$ \\
\hline Nephtys hombergii & & & & $0 \pm 0$ \\
\hline Ruditapes philippinarum & & & & $42 \pm 0$ \\
\hline Spionidae & & & & $0 \pm 0$ \\
\hline average abundance & $8049 \pm 1779$ & $3028 \pm 653$ & $2937 \pm 819$ & $4122 \pm 735$ \\
\hline
\end{tabular}



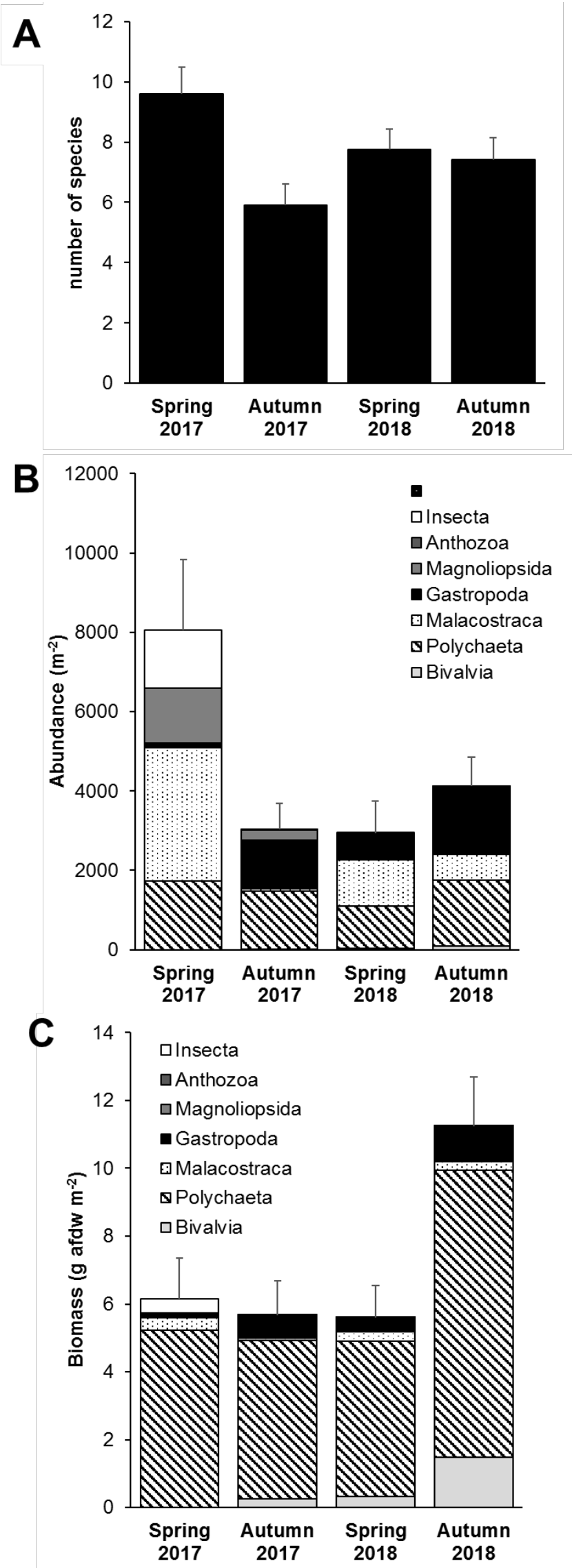

Figure 8 Variation in the mean ( \pm se) species richness $(A)$, total abundance $(B)$ and biomass (C) with proportional representation of the taxa in the Rammegors area. 

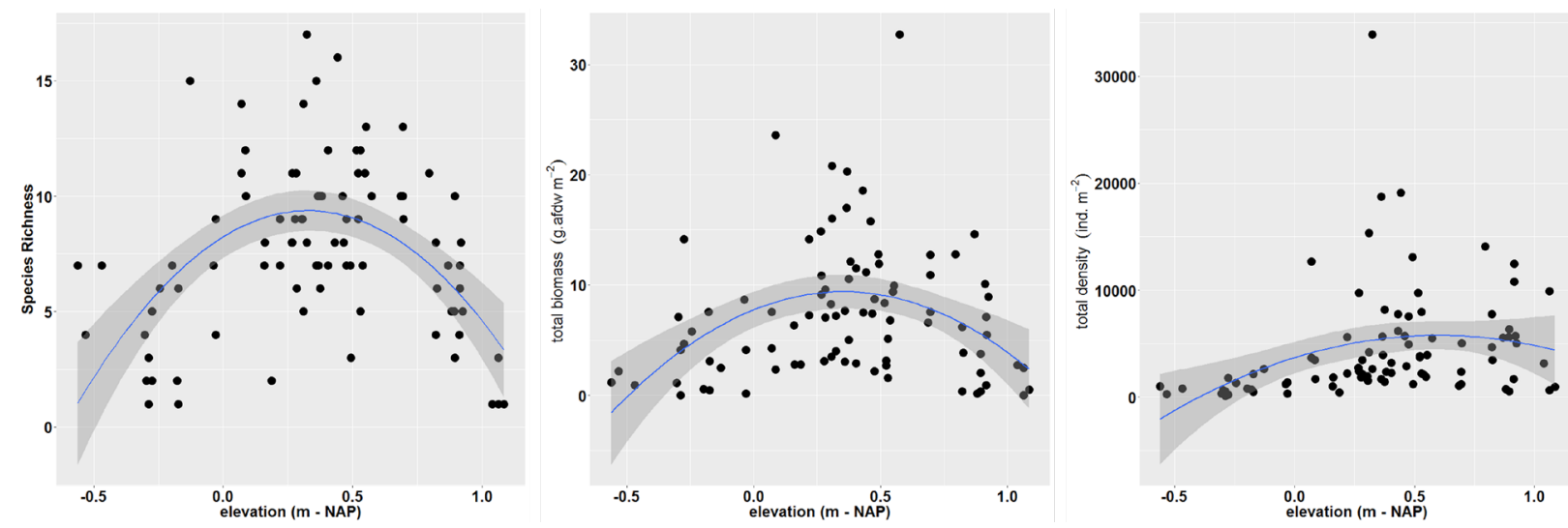

Figure 9 Species richness, total biomass and total density along an elevation gradient (in $\mathrm{m}$ NAP). Lines represent polynomial regression lines for the macrofauna community in the Rammegors area. Grey area indicate the $95 \%$ confidence interval.
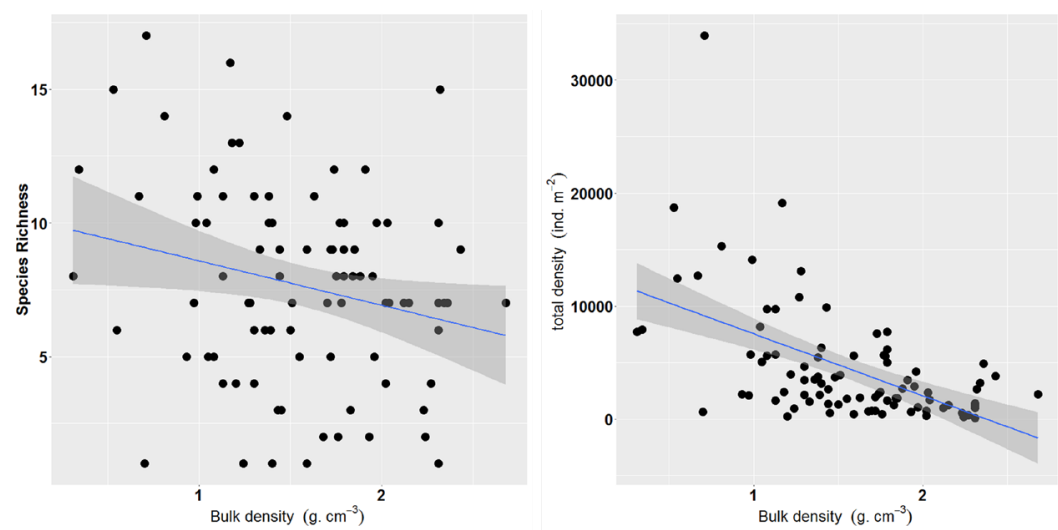

Figure 10 Species richness and total density versus Bulk density $\left(\mathrm{g} \mathrm{cm}^{-3}\right)$. Lines represent polynomial regression lines for the macrofauna community in the Rammegors area. Grey area indicate the $95 \%$ confidence interval.
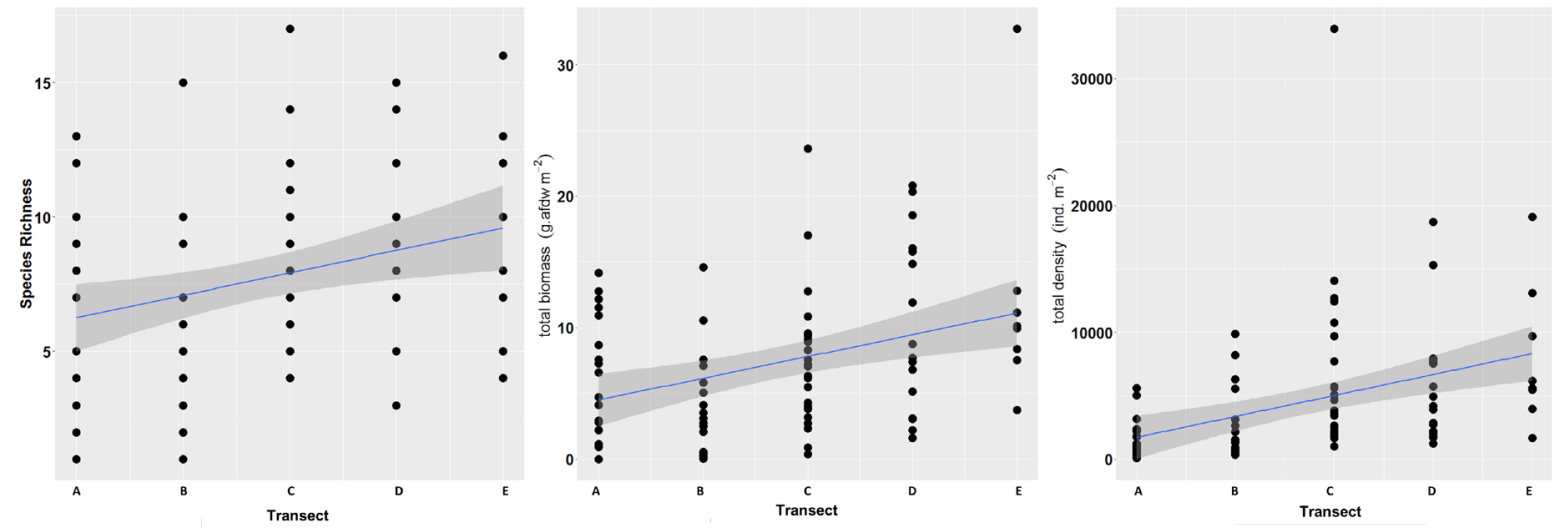

Figure 11 Species richness, total biomass and total density at the different transects increases with increasing distance to the inlet (transects A near the inlet). Lines represent linear regression lines for the macrofauna community in the Rammegors area. Grey area indicate the $95 \%$ confidence interval.

\subsection{Community structure}

The benthic community composition showed high dissimilarity between the first sampling moment in spring 2017 and the other sampling moments, indicating an initial transition. From autumn 2017 onwards the community did not show a clear trend (Figure 12). 


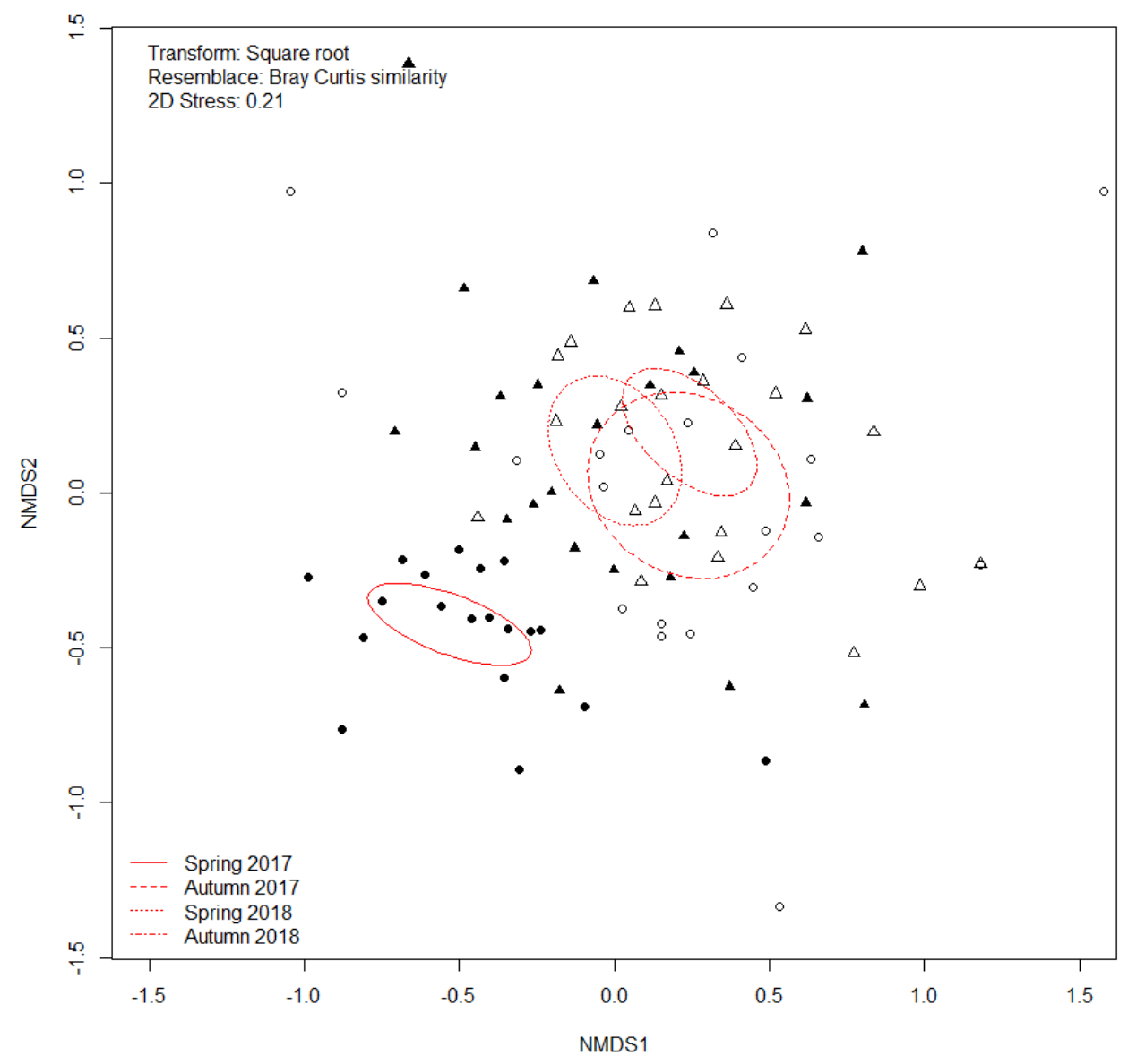

Figure 12 nMDS-plot showing changes in benthic community composition from spring 2017 till autumn 2018 at the Rammegors area based on abundance data. Each point represents a sampling station. The different symbols indicate the different sampling moments (closed circles: spring 2017; open circles: autumn 2017; closed triangles: spring 2018; open triangles: autumn 2018). Distance between points is a measure of dissimilarity in benthic community composition. The eclipse (red) denote the $95 \%$ confidence interval for each sampling moment. 


\section{$4 \quad$ Discussion and Conclusions}

A fast colonization of the benthic macrofauna was observed in Rammegors. The communities significantly differed between spring and autumn 2017 but did not show significant changes after autumn 2017. In spring densities reached high values, especially for the brackish mud shrimp Monocorophium insidiosum and mosquito larvae Chironomidae. In autumn these brackish species almost disappeared from the area. Their presence in autumn, even in low numbers, as well as the observation of the brackish cockle Cerastoderma glaucum indicate that, almost a year after the tidal restoration, parts of Rammegors are still under influence of brackish water. In spring a further decline occurred among the brackish species indicating the transition into a marine environment. The occurrence of brackish conditions a year after tidal inundation could be explained by model simulations of groundwater salinity by Deltares (van de Lageweg et al. 2019a). The occurrence of brackish conditions a year after tidal inundation could be explained by model simulations of groundwater salinity by Deltares (America et al. 2018). Before inundation, a freshwater lens was present in the Rammegors area. Inundation by saltwater influenced the groundwater. Saltwater is heavier then freshwater. The saltwater on top of the freshwater lens does not drain down homogeneous, but in plumes. As a response, also upward plumes of freshwater occur, resulting in locally seepage of freshwater to the surface. This could locally effect the benthic community as the ground water could be brackish at these spots whereas the overlaying water is saline (31).

Benthic macrofauna shows a relation with elevation. An optimum of species richness, total density and total biomass was found around +0.4m NAP with lower values at both lower and higher elevations.

As sedimentation does not take place in the Rammegors area no relation with sedimentation rate could be made. No relation between sediment composition and benthic macrofauna was found. With an increase in chlorophyll $a$ and organic matter an increase in total density was observed. A significant decrease in total density and species richness was observed with increasing bulk density, indicating that more compact sediments contain less species in lower abundances. With increasing distance from the inlet benthic macrofauna increases in richness, density and biomass. The elevation near the inlet was on average lower than the other transects, below the elevation at which an optimum in macrobenthic was observed. Sediment composition changes are larger near the inlet, perhaps calmer conditions further from the inlet facilitate the benthic macrofauna. Also retention time could be longer further from the inlet, affecting colonization processes. More knowledge on the hydrodynamics within the Rammegors area is needed to confirm this.

No comparison was made with a comparable ecotoop in the Oosterschelde as it is at this moment unclear which ecotoop is comparable with the Rammegors area due to the different tidal range in the Rammegors area compared to the Oosterschelde. A detailed inundation map of the area could help identifying with which area the Rammegors area could be compared.

Tidal restoration area Rammegors in the Oosterschelde developed different from the managed realignment Perkpolder located in the Westerschelde (van de Lageweg et al. 2019b). Biggest differences where (1) no sediment input in Rammegors, whereas a fast ongoing sedimentation occurs in Perkpolder and (2) the development of vegetation in Rammegors (Van de Lageweg et al. 2019a) compared to a lack of vegetation in Perkpolder (Van de Lageweg et al. 2019b). Besides those differences, both areas were initially colonized by a high numbers of Corophidae and showed a high biomass of Polychaeta. The community composition at Perkpolder is still showing large changes after five years and develops in the direction of a community generally found at the mid-litoral low-dynamic ecotoop at the transition zone between marine and brackish water of the Westerschelde. It is unknown after two years if the community in Rammegors reaches stability or that changes are too small to observed a development in a certain direction. Development of the benthic macrofauna community should be monitored over a longer period and compared to a community found in a comparable natural habitat. 


\section{Acknowledgement}

This report is part of the Rammegors monitoring project that was executed by the Centre of Expertise Delta Technology. This is a consortium formed by the University of Applied Sciences (Zeeland), Wageningen Marine Research, NIOZ and Deltares and financed by Rijkswaterstaat. This research was also partly financed by the Ministry of Public Affairs, within the framework of the Kennisbasis Programme System Earth Management (project KB-24-001-15). 


\section{Quality Assurance}

Wageningen Marine Research utilises an ISO 9001:2015 certified quality management system. This certificate is valid until 15 December 2021. The organisation has been certified since 27 February 2001. The certification was issued by DNV GL.

Furthermore, the chemical laboratory at IJmuiden has NEN-EN-ISO/IEC 17025:2005 accreditation for test laboratories with number L097. This accreditation is valid until $1^{\text {th }}$ of April 2021 and was first issued on 27 March 1997. Accreditation was granted by the Council for Accreditation. The chemical laboratory at IJmuiden has thus demonstrated its ability to provide valid results according a technically competent manner and to work according to the ISO 17025 standard. The scope (L097) of de accredited analytical methods can be found at the website of the Council for Accreditation (www.rva.nl).

On the basis of this accreditation, the quality characteristic $Q$ is awarded to the results of those components which are incorporated in the scope, provided they comply with all quality requirements. The quality characteristic $Q$ is stated in the tables with the results. If, the quality characteristic $Q$ is not mentioned, the reason why is explained.

The quality of the test methods is ensured in various ways. The accuracy of the analysis is regularly assessed by participation in inter-laboratory performance studies including those organized by QUASIMEME. If no inter-laboratory study is available, a second-level control is performed. In addition, a first-level control is performed for each series of measurements.

In addition to the line controls the following general quality controls are carried out:

- Blank research.

- Recovery.

- Internal standard

- Injection standard.

- Sensitivity.

The above controls are described in Wageningen Marine Research working instruction ISW 2.10.2.105. If desired, information regarding the performance characteristics of the analytical methods is available at the chemical laboratory at IJmuiden.

If the quality cannot be guaranteed, appropriate measures are taken. 


\section{References}

America, I., de Louw, P., Bier, G., van der Zee, S. (2018). Influence of tides, bathymetry, lithology and regional flows on the salinization process in nature area the Rammegors. In: 25th Salt Water Intrusion Meeting (SWIM 2018). - EDP Sciences, (E3S Web of Conferences) 25th Salt Water Intrusion Meeting, SWIM 2018, Gdansk, 2018-06-17/2018-06-22 - 6 p.

Aminot, A. \& Rey F. (2000). Standard procedure for the determination of chlorophyll a by spectroscopic methods. International Council for the Exploration of the Sea. ISSN $0903-$ 2606.

Craeymeersch J, Escaravage V (2014). Perceel Benthos. PMR Monitoring natuurcompensatie Voordelta. Eindrapport 1e fase 2009-2013 deel B. In: T. Prins and G. van der Kolff. Delft D (ed) Deltares rapport $1200672-Z K S-0043$

Crawford G (1937). A Review of the Amphipod Genus Corophium, with Notes on the British Species. Journal of the Marine Biological Association of the United Kingdom, 21(2), 589-630.

Elschot K, Tangelder M, IJzerloo van L, Van der Wal JT, Ysebaert T (2016). Getijdeherstel in het Rammegors; Een quick-scan van de effecten van een tijdelijke zoutwater instroom op een zoetwater natuurgebied. Wageningen Marine Research Wageningen UR (ed) Wageningen Marine Research rapport $\mathrm{C} 123 / 16$

Heip CHR, Goosen NK, Herman PMJ, Kromkamp J, Middelburg JJ, Soetaert K (1995). Production and consumption of biological particles in temperate tidal estuaries. Oceanography and Marine Biology Annual Reviews 33, 1-150.

Herman PMJ, Middelburg JJ, van de Koppel J, Heip CHR (1999). Ecology of estuarine macrobenthos. Advances in Ecology Research 29, 195-240.

Van de Lageweg, W., Stanic, N., Walles, B., Ysebaert, T., de Louw, P., Bouma, T., van Dalen, J. (2019a). Rammegors tidal restoration. HZ Report.

Van de Lageweg, W., Salvador de Paiva, J.N., de Vet, P.L.M, van der Werf, J., de Louw, P., Walles, B., Ysebaert, T., Bouma, T. (2019b). Perkpolder tidal restoration. HZ Report.

Ysebaert T, Craeymeersch JAM, van der Wal D (2016). De relatie tussen bodemdieren en hydro- en morfodynamiek in het sublitoraal en litoraal van de Westerschelde. In: IMARES (ed), Book (Rapport / IMARES C066/16) 


\section{Justification}

Report C042/19

Project Number: 4313100022

The scientific quality of this report has been peer reviewed by a colleague scientist and a member of the Management Team of Wageningen Marine Research

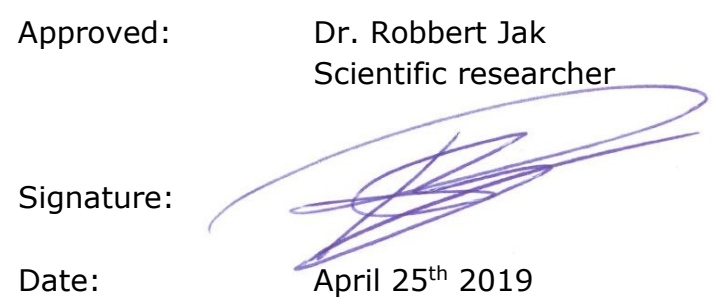

Approved: $\quad$ Drs. Jakob Asjes

Manager integration

Signature:

Date:

April 25th 2019 
Wageningen Marine Research

$\mathrm{T}+31(0) 317480900$

E: marine-research@wur.nl

www.wur.eu/marine-research

Visitors' address

- Ankerpark 271781 AG Den Helder

- Korringaweg 7, 4401 NT Yerseke

- Haringkade 1, 1976 CP IJmuiden
With knowledge, independent scientific research and advice, Wageningen Marine Research substantially contributes to more sustainable and more careful management, use and protection of natural riches in marine, coastal and freshwater areas.

Wageningen Marine Research is part of Wageningen University \& Research. Wageningen University \& Research is the collaboration between Wageningen University and the Wageningen Research Foundation and its mission is: 'To explore the potential for improving the quality of life' 